Q. Wang, et al., Int. J. Sus. Dev. Plann. Vol. 9, No. 5 (2014) 669-679

\title{
STUDY ON BIOMASS TAR REDUCTION BY ASH AND FLUIDIZING MEDIUM IN A HETEROGENEOUS REACTION
}

\author{
Q. WANG, T. ENDO, P. APARU \& H. KUROGAWA \\ Graduate School of Science and Engineering, Saitama University, Japan.
}

\begin{abstract}
Since fossil energy resources are exhaustible in the world, renewable biomass is considered as one of the useful future resources for energy and materials. In addition, when the biomass grows, it can contribute to the prevention of global warming by circularly absorbing $\mathrm{CO}_{2}$. There are different biomass utilization technologies such as the pyrolysis and gasification, fermentation and combustion. For example, gaseous components are used as chemical products and used for energy production; these can be produced by the pyrolysis or synthesized by gasification. However, there is the problem that condensable organic compounds, so-called 'tar' will also be generated during the pyrolysis and gasification processes. Most of the tar components are present as gases at higher temperature inside of the reactors. However, a black oily liquid will be formed, leading to the equipment failure when the temperature is cooled down lower than their boiling points. Therefore, appropriate processing is required. As a processing method, catalytic decomposition of tar has been widely studied. In the present study, it was carried out for the thermal decomposition of cellulose in the experimental apparatus connecting two reaction tubes. Tar and gases generated by the thermal decomposition of cellulose in the first reactor can be pyrolyzed with catalytic cracking in the second reactor. Tar contents were firstly cooled and collected. At the same time, the amount of gases was measured by a gas chromatograph with a flame ionization detector and a gas chromatograph with a thermal conductivity detector. Then, $\mathrm{K}$ and $\mathrm{Ca}$ were selected as the catalyst of alkali metals and alkaline earth metals contained in the waste biomass, which were present in the state of oxide or carbonate during the pyrolysis and gasification. The amount of condensable products was decreased by installing catalytic contents of $\mathrm{K}_{2} \mathrm{CO}_{3}$ and $\mathrm{Ca}(\mathrm{OH})_{2}$. Additionally, the amount of gaseous products was increased. It can be concluded that an alkali metal compound $\left(\mathrm{K}_{2} \mathrm{CO}_{3}\right)$ and an alkaline earth compound $(\mathrm{CaO})$ have a catalytic effect to decompose tar contents, which can enhance gaseous production in the secondary reaction.

Keywords: Alkaline earth metal, alkali metal, biomass, pyrolysis, fluidizing medium, heterogeneous reaction, tar catalytic reduction.
\end{abstract}

\section{INTRODUCTION}

The amount of energy consumption has increased in the world, especially in the developing countries. Petroleum oil, coal and natural gas are the exhaustible resources to fulfill the energy requirement in the world. Large amounts of carbon dioxide emissions occur when these former energy resources are consumed, promoting global warming. Recently, attention has been attracted toward the use of biomass as a renewable energy resource. Generally, biomass resources are present throughout the world. Thermal decomposition and gasification methods are used to derive energy from biomass. Thermal decomposition is the reaction for generating gas $\left(\mathrm{H}_{2}, \mathrm{H}_{2} \mathrm{O}, \mathrm{CO}, \mathrm{CO}_{2}\right.$ and $\left.\mathrm{C}_{\mathrm{m}} \mathrm{H}_{\mathrm{n}}\right)$, tar and char by heating the biomass. Gasification is the reaction for generating further gas and ash by heating the char with a gasifying agent. The gas obtained by the thermal decomposition and gasification mainly composed of $\mathrm{H}_{2}$ and $\mathrm{CO}$. These gases are used as fuel and for further synthesis of ammonia, liquid fuel, methanol, chemical products and a variety of derivative products [1]. However, the amount of condensable organic compound called tar is produced during the thermal decomposition and gasification. Tar clogs the pipe of gasifier and breaks the turbine. Mechanical methods cannot recover energy from tar that are just removed from gaseous products, while thermal cracking requires high temperature $\left(>1100^{\circ} \mathrm{C}\right)$ to convert them [2]. The catalytic tar decomposition has been proposed to overcome these drawbacks. In addition, the catalyst can enhance gas formation and modify the 
gaseous composition by promoting the reforming reactions of hydrocarbons. Tar reduction using a catalyst has been extensively studied. It has been reported that nickel-based catalysts, alkaline metal oxides and alkaline earth metal oxides are suitable to reduce the amount of tar [3]. Alkali metal and alkaline earth metal are present in the ash component of the biomass. Therefore, the possibility of tar reduction by ash in the biomass can be considered.

A fluidized bed and spouted bed system are very important for the tar reduction. Because the contact efficiency between tar and ash is high by blowing a gasifying agent, tar reduction by heterogeneous reaction also occur in these gasifiers. The thermal decomposition and gasification of biomass in a fixed-bed system have been widely studied, but the heterogeneous reaction between tar and ash has not yet been studied [4]. The significant catalytic effect of the ash can be evaluated using an experimental system that performs the heterogeneous reaction between tar and ash in a fluidized bed gasifier. It is well known that cellulose is a major component of wood and plant biomass [5]. Therefore, an experiment was conducted to determine the thermal decomposition of cellulose by constructing an experimental device that performs the heterogeneous reaction in a fluidized bed gasifier. Since catalytic heterogeneous reaction of ash with tar was achieved, the thermal decomposition experiment of cellulose was carried out by adding the tar products to the ash contents. The yields of char were calculated from the results of the thermogravimetric differential thermal analysis (TG-DTA) experiment. The condensable products of tar were cooled down and collected in a test tube to measure the yields, and the yields of gas were measured by a gas chromatograph with a flame ionization detector (GC-FID) and a gas chromatograph with a thermal conductivity detector (GCTCD). More detailed results in this study newly added the debate on the contents of the conference paper published in 4th International Conference on Energy and Sustainability [6].

\section{MATERIALS AND METHODS}

\subsection{Materials}

The experimental sample was the microcrystalline cellulose with an average diameter of $50 \mu \mathrm{m}$ SERVA Electrophoresis GmbH. The chemical formula of this sample polymer could be approximated as $\left(\mathrm{C}_{6} \mathrm{H}_{6} \mathrm{O}_{5}\right) n$, by confirming the linearly polymerized structure of the glucopyranose linked by $\beta$-1, 4-glycosidic bonds. The elemental analysis of cellulose was performed using a CHN corder (Model MT-5; Yanaco Co. Ltd., Japan), and proximate analysis was also performed. The composition of cellulose is shown in Table 1 .

Potassium and calcium were present as the catalytic species of alkali metal and alkaline earth metals in the ash contents of biomass. In this study, $\mathrm{K}_{2} \mathrm{CO}_{3}$ (Wako, Pure chemicals, Co. Ltd., Japan, assay minimum $99.5 \%$ ) and $\mathrm{Ca}(\mathrm{OH})_{2}$ (Wako, assay minimum $96.0 \%$ ) were used as model catalytic ash contents. In the gasification apparatus, it was assumed that alkali metal and alkaline earth metal species were present as oxides or carbonates. Silicon dioxide was used as a fluidizing medium.

Table 1: Elemental analysis and proximate analysis of cellulose.

\begin{tabular}{lccccccc}
\hline \multicolumn{3}{l}{ Elemental analysis $(w t \%)$} & \multicolumn{4}{c}{ Proximate analysis (wt\%) } \\
\hline $\mathrm{C}$ & $\mathrm{H}$ & $\mathrm{N}$ & $\mathrm{O}$ & Moisture & Volatiles & Fixed carbon & Ash \\
\hline 43.31 & 6.23 & 0.00 & 50.46 & 7.18 & 86.90 & 5.92 & 0.00 \\
\hline
\end{tabular}


As fluidizing medium was present in the gasifier, high temperature was maintained in the furnace and biomass was dispersed [7].

\subsection{TG-DTA experiment for cellulose pyrolysis behavior}

The pyrolysis of cellulose was carried out in a thermogravimetric differential thermal analyzer (TG-DTA, Model DTG-60; Shimadzu Co. Ltd., Japan) to calculate the yield of char and to study the pyrolysis behavior. About 5.00-7.00 mg of sample was placed on the scales in the apparatus. The sample was heated up to $900^{\circ} \mathrm{C}$ at a constant heating rate of $10^{\circ} \mathrm{C} / \mathrm{min}$. Argon at a flow rate of $70 \mathrm{ml} / \mathrm{min}$ was used as the carrier gas to provide an inert atmosphere for the pyrolysis and to remove the gaseous and condensable products.

\subsection{Thermal decomposition of cellulose}

\subsubsection{Experimental apparatus for cellulose pyrolysis and gasification}

The scheme of the experimental setup used for cellulose pyrolysis and gasification is shown in Fig. 1. It was composed of gas feeding system, pyrolysis system, tar decomposition system, condensable products trapping system and gaseous products measurement system. Pyrolysis system and tar decomposition system consisted of the two stainless connecting reactors (Inner Diameter: $21.4 \mathrm{~mm}$, length: $500 \mathrm{~mm})$. Cellulose, $\mathrm{K}_{2} \mathrm{CO}_{3}, \mathrm{Ca}(\mathrm{OH})_{2}$ and silicon dioxide were placed on the mesh $(40 \mu \mathrm{m})$ in each reactor. This apparatus can be independently heated in two different electric furnaces while the gas mixture coming in contact with the catalyst. Therefore, heterogeneous reaction between tar and ash can be carried out using the apparatus. The lines between the first and second reactor as well as between the second reactor and the condensable products trapping the system were heated at the temperature of around $300^{\circ} \mathrm{C}-400^{\circ} \mathrm{C}$ to avoid the condensation of tar. The condensable products were collected by cooling the test tube, and the collection efficiency was improved by using glass beads. The cooling bath was kept below $-3^{\circ} \mathrm{C}$ by mixing water, ice and sodium chloride.

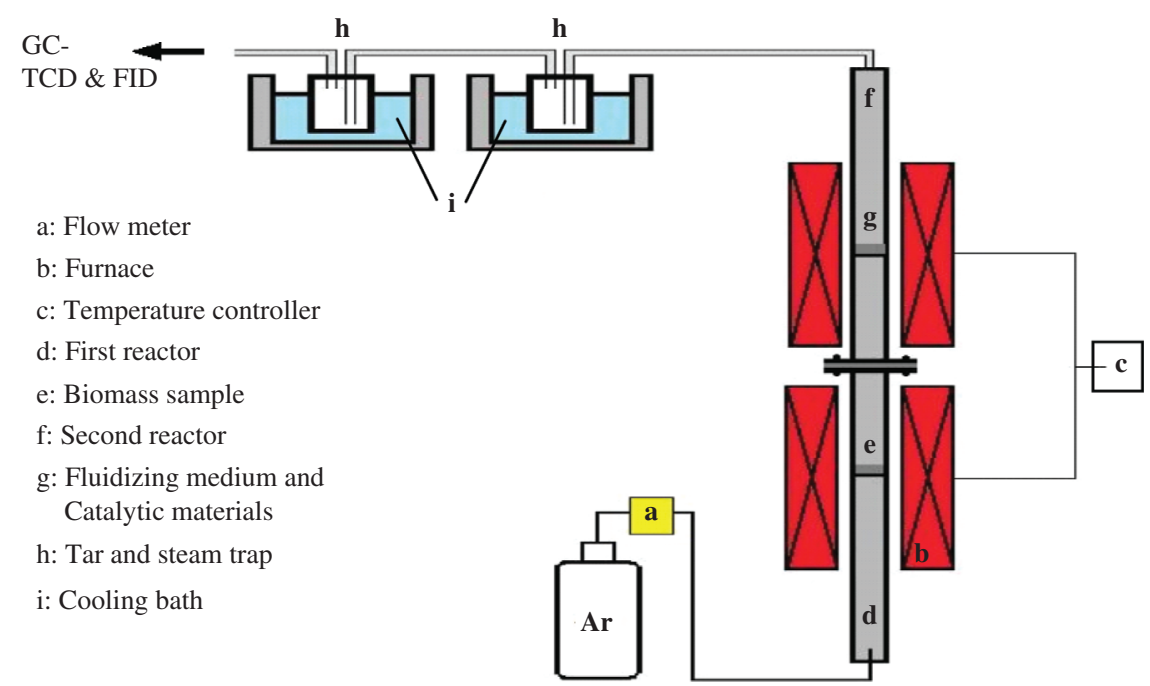

Figure 1: Experimental setup for cellulose pyrolysis and gasification. 
Table 2: Experimental conditions used for tests.

\begin{tabular}{lcccc}
\hline & & \multicolumn{3}{c}{ Second reactor } \\
\cline { 3 - 5 } Item & First reactor & none & $\mathrm{K}_{2} \mathrm{CO}_{3}$ & $\mathrm{Ca}(\mathrm{OH})_{2}$ \\
\hline Cellulose amount $(\mathrm{g})$ & 2.00 & - & 0.691 & 0.741 \\
Catalyst amount $(\mathrm{g})$ & - & 5.00 & 4.309 & 4.259 \\
Silicon dioxide amount $(\mathrm{g})$ & - & & - & \\
Heating rate $\left({ }^{\circ} \mathrm{C} / \mathrm{min}\right)$ & 10 & 500,700, & 700,800 & 700,800 \\
Maximum temperature $\left({ }^{\circ} \mathrm{C}\right)$ & 900 & 800,900 & \\
Argon flow rate $(\mathrm{ml} / \mathrm{min})$ & \multicolumn{5}{c}{70} \\
\hline
\end{tabular}

The gaseous products were measured by a GC-TCD/FID (Model GC-2014; Shimadzu Co. Ltd., Japan). In this study, ten kinds of gas were determined as gaseous products. $\mathrm{H}_{2}, \mathrm{CO}, \mathrm{CH}_{4}$ and $\mathrm{CO}_{2}$ were measured by a GC-TCD, while hydrocarbons $\left(\mathrm{C}_{2} \mathrm{H}_{6}\right.$ and $\mathrm{C}_{2} \mathrm{H}_{4}, \mathrm{C}_{3} \mathrm{H}_{8}, \mathrm{C}_{3} \mathrm{H}_{6}$, iso- $\mathrm{C}_{4} \mathrm{H}_{10}$, n- $\mathrm{C}_{4} \mathrm{H}_{10}$ ) were measured by a GC-FID.

\subsubsection{Experimental procedures}

The operative conditions of the experiment are reported in Table 2. Cellulose, catalysts, and silicon dioxide were placed in each reactor under the conditions given in Table 2. The second reactor was heated up to a predetermined temperature under argon at a constant flow rate. Then, the first reactor was heated up (up to $900^{\circ} \mathrm{C}$ at $10^{\circ} \mathrm{C} / \mathrm{min}$ ), and the gaseous products were measured at each $80^{\circ} \mathrm{C}$ interval from $180^{\circ} \mathrm{C}$ to $900^{\circ} \mathrm{C}$ by a GC-TCD/FID.

\subsubsection{Yields of pyrolysis products}

The yields of char were calculated by TG-DTA analysis. The yields of condensable products were determined by the weight difference of the test tube before and after the experiment. The yields of gaseous products were calculated from the measurement results of GC-TCD/FID. Also, the yields of residue materials were calculated by subtracting the amount of char, the amount of condensable products and the amount of gaseous products from the amount of cellulose. The residue materials were deposited as coke on the catalyst surface and the secondary products of char remained in the apparatus.

\section{RESULTS AND DISCUSSIONS}

\subsection{The behavior of cellulose pyrolysis from TG-DTA analysis}

The pyrolysis characteristics, both TG (wt \%) and DTA $(\mu \mathrm{V})$ curves, of cellulose were determined with a TG-DTA (Fig. 2). Rapid weight loss of cellulose was observed from $300^{\circ} \mathrm{C}$ to $400^{\circ} \mathrm{C}$, and then the weight loss progressed slowly. The endothermic peak observed at the temperature ranging from $300^{\circ} \mathrm{C}$ to $400^{\circ} \mathrm{C}$ indicates that the thermal decomposition of cellulose occurred in this temperature range [8]. Furthermore, the weight loss was also observed in the same temperature range. Thus, it should be predicted that a large amount of thermal decomposition products had been released in this temperature range. But slow weight loss was continued after $400^{\circ} \mathrm{C}$. This indicated that a small amount of thermal decomposition products had been released. When the temperature was higher than $400^{\circ} \mathrm{C}$, almost all cellulose was pyrolyzed and a very low amount of solid residue 


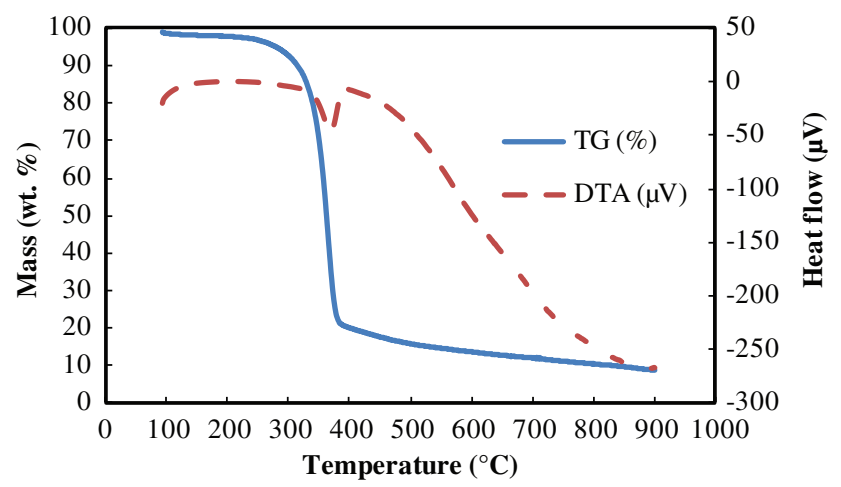

Figure 2: Pyrolysis curves of cellulose during the TG-DTA analysis.

was left. Experiments were carried out several times under the same conditions with $\pm 5 \%$ maximum error. Thus, in this study, the yields of char from cellulose pyrolysis were calculated as 8.90 (wt $\%$ ).

\subsection{Thermal decomposition of cellulose}

\subsubsection{Effect of pyrolysis temperature}

The molar quantity (mmol/g-cellulose) of $\mathrm{H}_{2}$ and $\mathrm{CO}$ generated by the thermal decomposition of cellulose in each second reactor temperature conditions is described in Figs 3 and 4, respectively. The molar quantity of $\mathrm{H}_{2}$ increased with the increase in the second reactor temperature. The molar quantity of $\mathrm{H}_{2}$ was maximum when the second reactor temperature was $900^{\circ} \mathrm{C}$, but it was minimum at $500^{\circ} \mathrm{C}$. When the second reactor temperature was $500^{\circ} \mathrm{C}$, the generation of $\mathrm{H}_{2}$ began to increase rapidly after about $600^{\circ} \mathrm{C}$. At other second reactor temperature conditions, the generation of $\mathrm{H}_{2}$ was also observed in that temperature range. However, $\mathrm{H}_{2}$ generation was remarkable between $300^{\circ} \mathrm{C}$ and $500^{\circ} \mathrm{C}$. When the second reactor temperature reached $500^{\circ} \mathrm{C}$, only a small amount of $\mathrm{H}_{2}$ was generated in that temperature range.

The molar quantity of $\mathrm{CO}$ increased with the increase in the second reactor temperature. When the second reactor temperature was $900^{\circ} \mathrm{C}$, the molar quantity of $\mathrm{CO}$ was maximum, while it was minimum at $500^{\circ} \mathrm{C}$. The generation of $\mathrm{CO}$ was remarkable from $300^{\circ} \mathrm{C}$ to $500^{\circ} \mathrm{C}$ in all second reactor conditions. The molar quantity of all gas species increased with the increase in the second reactor temperature; it may be happened for the secondary pyrolysis reaction of cellulose pyrolysis products in the second reactor. It seems that a large amount of pyrolysis products have been pyrolyzed again and have contributed to the active gas generation at the temperatures ranging from $300^{\circ} \mathrm{C}$ to $500^{\circ} \mathrm{C}$. Heavier tar could be pyrolyzed at higher second reactor temperature; thus, the generation of additional gas and carbon constituent could be expected. In different temperatures, a large amount of gas was produced from the secondary pyrolysis and gasification of tar compared with that from the primary pyrolysis. That could be the reason for the significant difference in the molar quantity of gas production [9]. In the case of second reactor temperature at $500^{\circ} \mathrm{C}$, it can be estimated that the secondary pyrolysis and gasification of tar was not occurred much. The molar quantity of $\mathrm{H}_{2}$ was low, since the remarkable generation of $\mathrm{H}_{2}$ was not observed from $300^{\circ} \mathrm{C}$ to $500^{\circ} \mathrm{C}$ when the temperature of second reactor was $500^{\circ} \mathrm{C}$.

The pyrolysis experiment of cellulose has been performed to evaluate the secondary pyrolysis and gasification of tar. The first reactor was empty and was not heated. Cellulose $(2.00 \mathrm{~g})$ was placed in the second reactor. Then, the second reactor was heated up (at $10^{\circ} \mathrm{C} / \mathrm{min}$ up to $900^{\circ} \mathrm{C}$ ) and the 


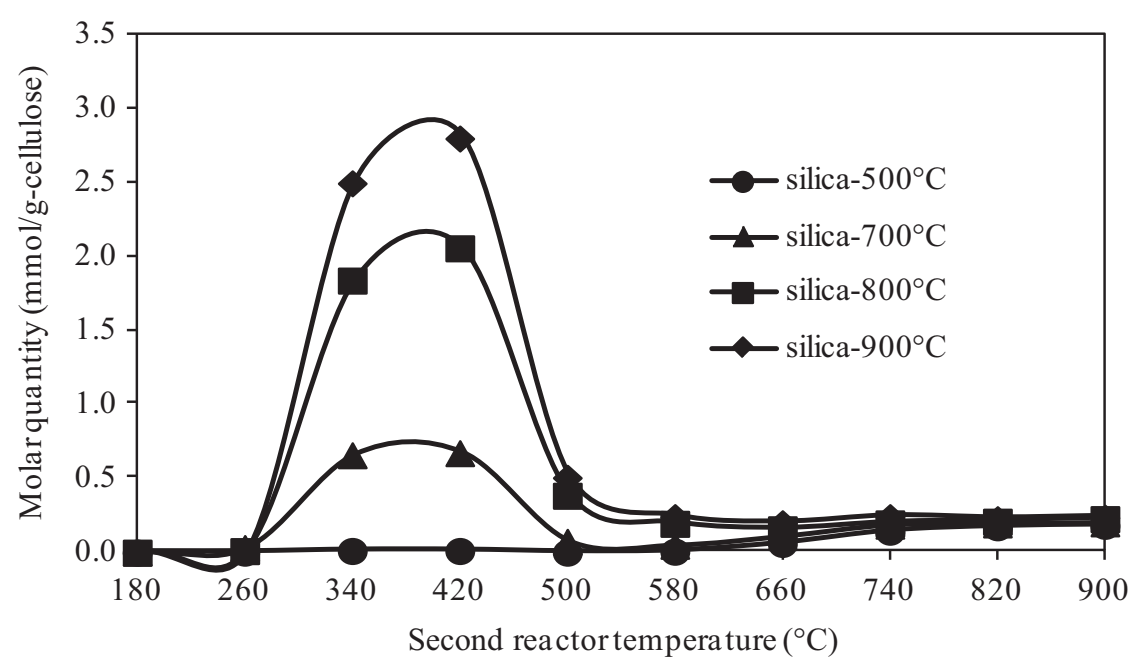

Figure 3: Molar quantity of $\mathrm{H}_{2}$ at different second reactor temperatures.

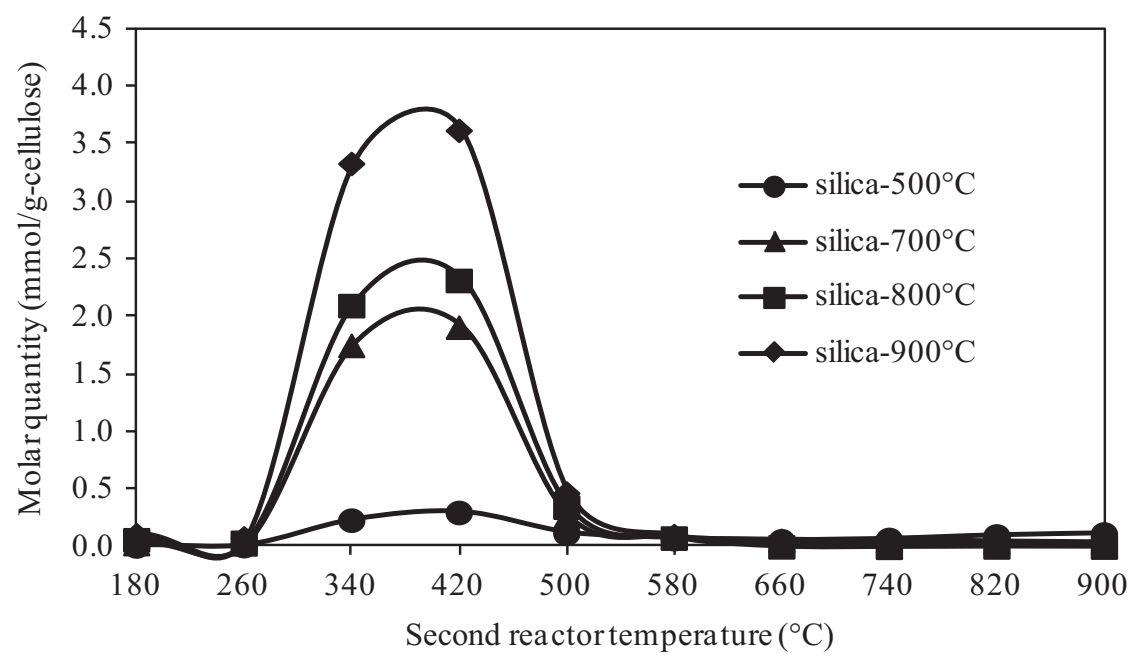

Figure 4: Molar quantity of $\mathrm{CO}$ at different second reactor temperatures.

gaseous products were measured at each $80^{\circ} \mathrm{C}$ interval from $180^{\circ} \mathrm{C}$ to $900^{\circ} \mathrm{C}$ by a GC-TCD/FID. Figure 5 shows the gaseous products profiles of cellulose pyrolysis only (a) and silica- $500^{\circ} \mathrm{C}$ (b). The molar quantity at the experimental condition (b) was slightly more than at the experimental condition (a) in all gas species. In the case of experimental condition (a), $\mathrm{H}_{2}$ generation was not observed between $300^{\circ} \mathrm{C}$ and $500^{\circ} \mathrm{C}$, but it was observed at $600^{\circ} \mathrm{C}$ and more than that. From these results, it could be considered that the secondary pyrolysis and gasification of tar was occurred at $500^{\circ} \mathrm{C}$ in the second reactor but the effect was very small.

The mass balance of cellulose pyrolysis products in each second reactor conditions are given in Fig. 6. The amount of condensable products was decreased with the increase in the second reactor 

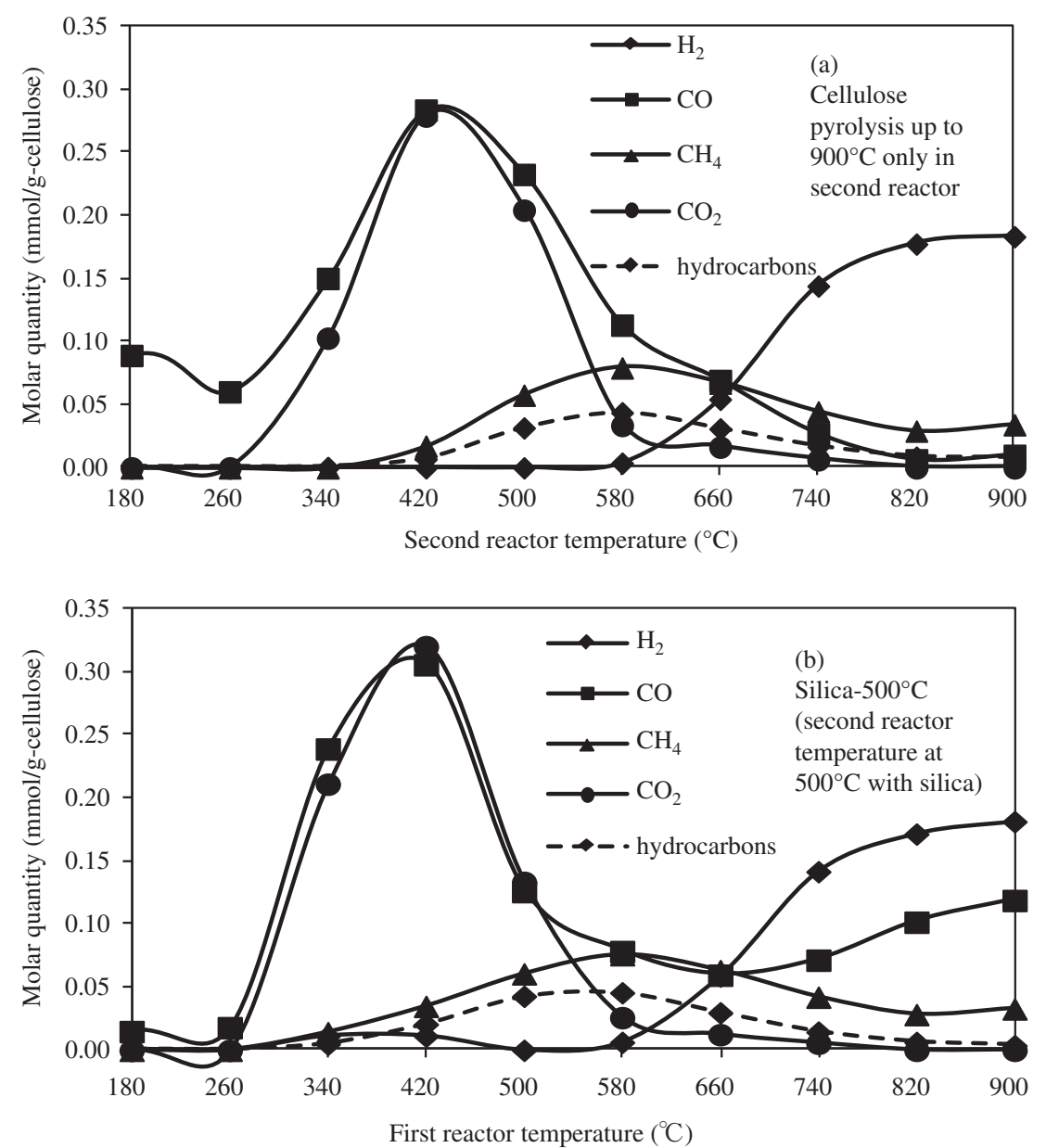

Figure 5: Gaseous products profiles of (a) cellulose pyrolysis up to $900^{\circ} \mathrm{C}$ only in second reactor, and (b) cellulose pyrolysis up to $900^{\circ} \mathrm{C}$ in first reactor when second reactor temperature at $500^{\circ} \mathrm{C}$ with silica $\left(\right.$ silica- $\left.500^{\circ} \mathrm{C}\right)$.

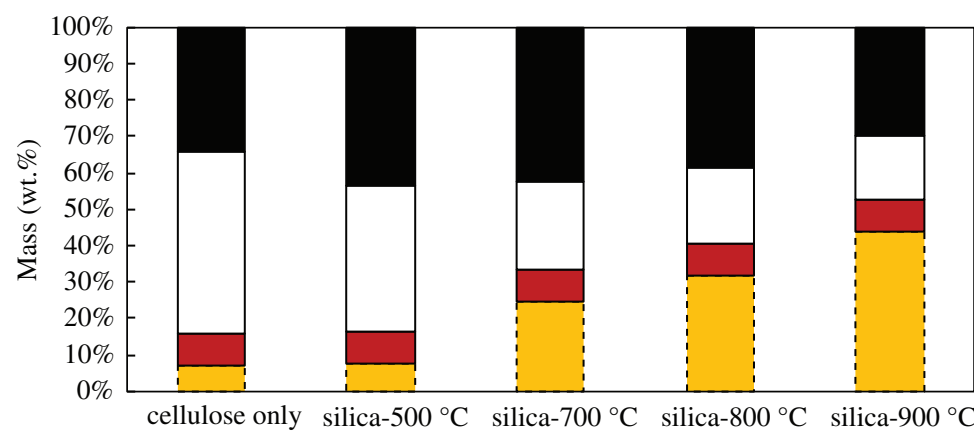

- Residual materials $\square$ Condensable products $\square$ Char :I Gaseous products

Figure 6: Mass balance of cellulose pyrolysis products under second reactor conditions. 
temperature. When the second reactor temperature was $900^{\circ} \mathrm{C}$, the amount of condensable products was less. While the second reactor temperature was $500^{\circ} \mathrm{C}$, the amount of gaseous products increased about $9.5 \%$ and the amount of condensable products decreased about $19.8 \%$ compared with cellulose only and the amount of residual materials increased. However, in the case of cellulose only, the amount of residual materials was comparatively less.

In the second reactor, it could be estimated that coke was produced by the secondary pyrolysis and gasification of tar, while in the case of cellulose pyrolysis only, these reactions did not occur. Therefore, the production of coke was limited. It can be estimated that further gas generation was occurred due to the reaction of coke with pyrolysis product gas. It can be concluded that temperature conditions of the secondary pyrolysis and gasification of tar are very important to reduce tar products.

\subsubsection{Catalytic effect on cellulose during the thermal decomposition}

The molar quantity (mmol/g-cellulose) of $\mathrm{H}_{2}$ and $\mathrm{CO}$ is indicated in Figs 7 and 8, respectively, which were produced by the thermal decomposition of cellulose when the catalyst was added. The molar quantity of $\mathrm{H}_{2}$ increased approximately $10.3 \%$ after adding $\mathrm{K}_{2} \mathrm{CO}_{3}$ compared with the molar quantity observed at the presence of silicon dioxide only at $700^{\circ} \mathrm{C}$. However, the total quantity of $\mathrm{H}_{2}$ increased nearly $80.1 \%$ after adding $\mathrm{Ca}(\mathrm{OH})_{2}$. Compared with the presence of silicon dioxide only in the second reactor at $800^{\circ} \mathrm{C}$, the molar quantity of $\mathrm{H}_{2}$ increased about $4.3 \%$ and $23.4 \%$ when $\mathrm{K}_{2} \mathrm{CO}_{3}$ and $\mathrm{Ca}(\mathrm{OH})_{2}$ were added, respectively.

The molar quantity of $\mathrm{CO}$ increased about $15.8 \%$ with the increase of the second reactor temperature from $700^{\circ} \mathrm{C}$ to $800^{\circ} \mathrm{C}$. Comparing with the presence of silicon dioxide only in the second reactor at $700^{\circ} \mathrm{C}$, the molar quantity of $\mathrm{CO}$ increased about $49.5 \%$ after adding $\mathrm{Ca}(\mathrm{OH})_{2}$. The molar quantity of $\mathrm{CO}$ was higher than those at the temperature raised condition $\left(700^{\circ} \mathrm{C}-800^{\circ} \mathrm{C}\right)$ when $\mathrm{Ca}(\mathrm{OH})_{2}$ was added without changing the temperature of the second reactor.

In the case of same temperature conditions in the second reactor, the molar quantity of all gas species increased after adding $\mathrm{K}_{2} \mathrm{CO}_{3}$ and $\mathrm{Ca}(\mathrm{OH})_{2}$. On the basis of these results, it can be concluded that addition of $\mathrm{K}_{2} \mathrm{CO}_{3}$ and $\mathrm{Ca}(\mathrm{OH})_{2}$ significantly increased gas production. The amount of gas produced was relatively higher in the presence of $\mathrm{Ca}(\mathrm{OH})_{2}$ than $\mathrm{K}_{2} \mathrm{CO}_{3}$.

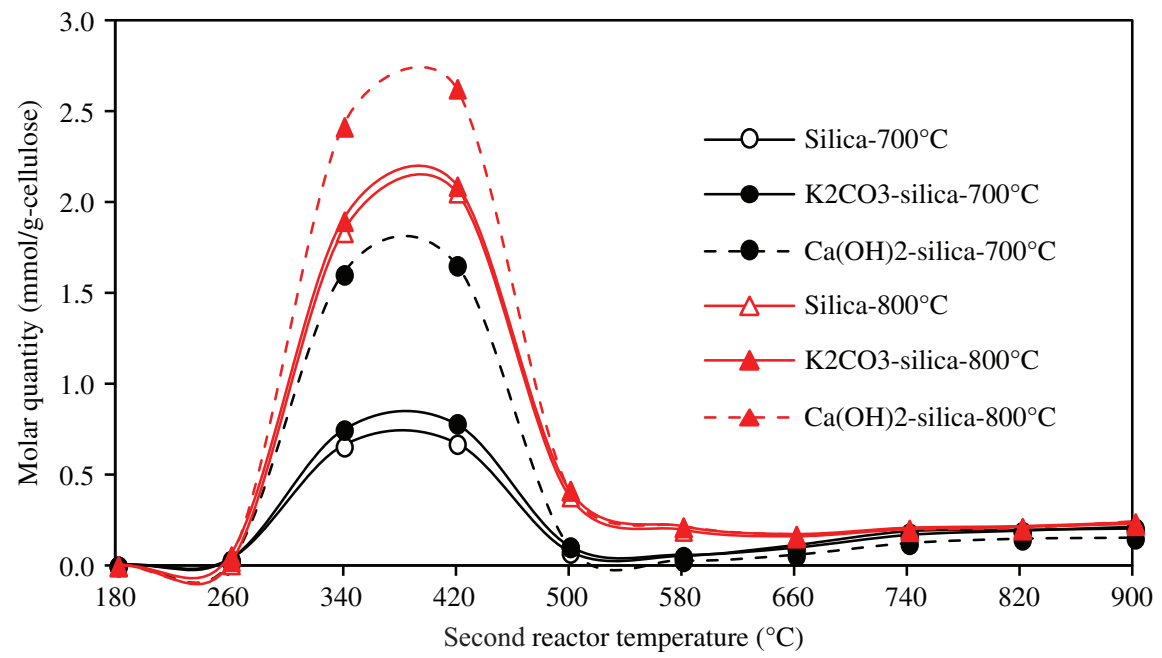

Figure 7: Molar quantity of $\mathrm{H}_{2}$ under second reactor conditions. 


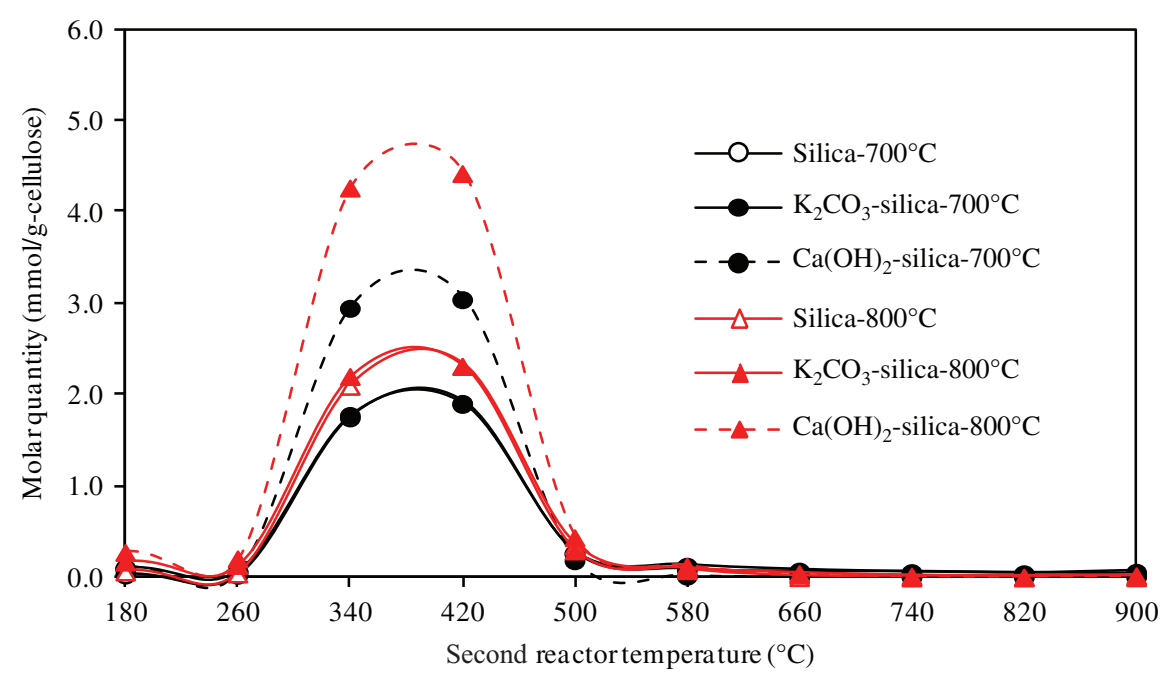

Figure 8: Molar quantity of $\mathrm{CO}$ under second reactor conditions.

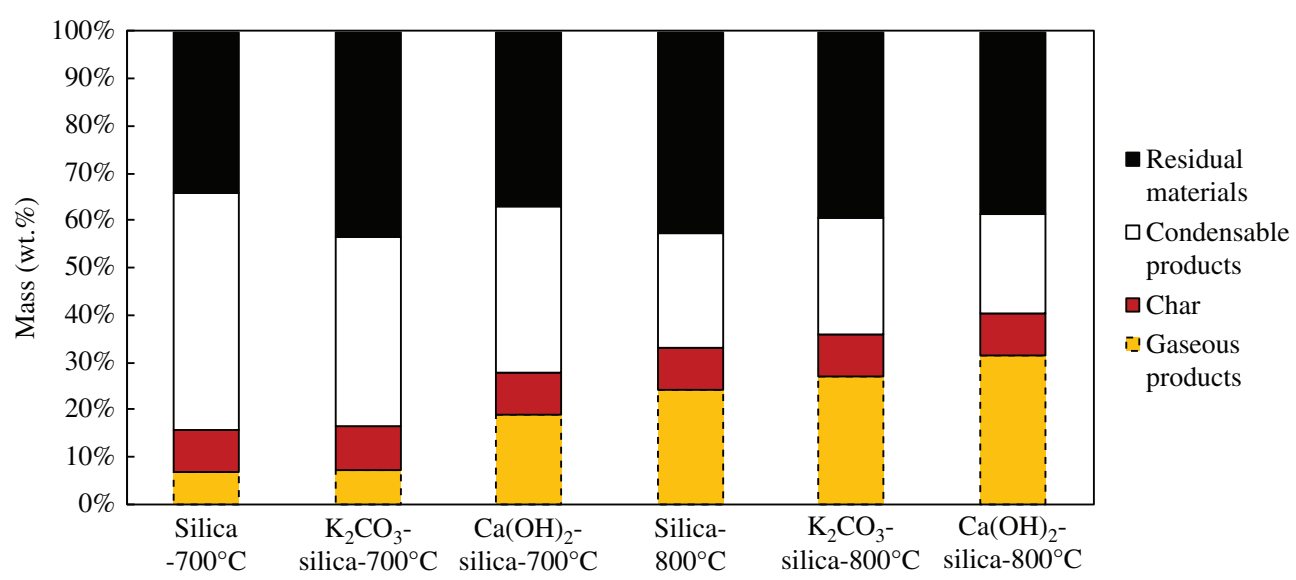

Figure 9: Mass balance of cellulose pyrolysis products in the case of installed catalysts.

The mass balance of cellulose pyrolysis products in the case of installed catalysts is presented in Fig. 9. The amount of gaseous products increased about $12.4 \%$ after adding $\mathrm{K}_{2} \mathrm{CO}_{3}$ compared with the presence of silicon dioxide only at $700^{\circ} \mathrm{C}$. However, the amount of gaseous products increased nearly $48.5 \%$ after adding $\mathrm{Ca}(\mathrm{OH})_{2}$ compared with the presence of silicon dioxide only in the second reactor at $800^{\circ} \mathrm{C}$. The amount of gaseous products increased about $19.1 \%$ and $71.3 \%$ in the presence of $\mathrm{K}_{2} \mathrm{CO}_{3}$ and $\mathrm{Ca}(\mathrm{OH})_{2}$, respectively. The amount of condensable products decreased about $0.6 \%$ after adding $\mathrm{K}_{2} \mathrm{CO}_{3}$ compared with the condition where silicon dioxide only was placed in the second reactor at $700^{\circ} \mathrm{C}$. However, it decreased nearly $4.8 \%$ when $\mathrm{Ca}(\mathrm{OH})_{2}$ was added. The amount of condensable products decreased nearly $11.9 \%$ and $18.0 \%$ in the presence of $\mathrm{K}_{2} \mathrm{CO}_{3}$ and $\mathrm{Ca}(\mathrm{OH})_{2}$, respectively, compared with the presence of silicon dioxide only in the second reactor at $800^{\circ} \mathrm{C}$. On the basis of the current findings, it can be concluded that $\mathrm{K}_{2} \mathrm{CO}_{3}$ and $\mathrm{Ca}(\mathrm{OH})_{2}$ have an 
effect on tar decomposition. Also, it can be estimated that tar was decomposed by the catalyst, which produced coke on the catalyst surface. Subsequently, it reacted with pyrolysis product gas, which increased the amount of gaseous products. Therefore, the residual materials decreased. In this study, the amount of residual materials was approximately $20 \%-40 \%$. It is guessed that residual materials can be a source of gas in the presence of gasifying agent and under high temperature conditions. $\mathrm{Ca}(\mathrm{OH})_{2}$ has more catalytic effect than $\mathrm{K}_{2} \mathrm{CO}_{3}$. But the role of $\mathrm{K}_{2} \mathrm{CO}_{3}$ might have been underestimated. Because $\mathrm{K}_{2} \mathrm{CO}_{3}$ reacts with silicon dioxide to form glass at the temperature around $800^{\circ} \mathrm{C}$ [10]. Furthermore, in this study, the weight ratio of $\mathrm{K}_{2} \mathrm{CO}_{3}$ and silicon dioxide in the glass was similar to the previous literature [11]. The melting temperature of $\mathrm{K}_{2} \mathrm{CO}_{3}$ is around $900^{\circ} \mathrm{C}$. Thus, in this study, $\mathrm{K}_{2} \mathrm{CO}_{3}$ did not decompose into $\mathrm{K}_{2} \mathrm{O}$ and $\mathrm{CO}_{2}$ [12]. In fluidized bed gasifier, it has been reported that fluidizing medium reacts with alkali metal and alkaline earth metal in the ash. Such an agglomeration reaction brings about defluidization [13]. It can be considered that the agglomeration reaction in this study was mainly derived from inorganic materials, not from the organic materials such as tar, because the catalyst and silica were heated previously. It was suggested to consider reactivity between the catalysts and fluidizing medium. In this study, $\mathrm{Ca}(\mathrm{OH})_{2}$ existed in a state of $\mathrm{CaO}$. Under high temperature, tar and secondary product char adhere to its surface [14]. Adhering material reacts with the pyrolysis product gases, which are further produced. Additionally, the polarity of the active site of $\mathrm{CaO}$ can affect the $\pi$-electron cloud's stability of condensed aromatic compounds, and $\mathrm{CaO}$ itself has a cracking active site on both inner and outer surfaces [15].

\section{CONCLUSIONS}

In this study, the thermal decomposition of cellulose has been carried out using an experimental apparatus connecting the two reaction tubes. The apparatus could perform the heterogeneous reaction between tar and ash in a fluidized bed gasifier. When the second reactor temperature increased, the secondary pyrolysis reaction of cellulose pyrolysis products in the second reactor was promoted. Consequently, the production of gas increased and that of tar decreased. Alkali metal K and alkaline earth metal $\mathrm{Ca}$ were selected as the catalytic contents because of their considerable presence in biomass. They may act as the catalytic contents for tar decomposition. As the catalytic effect of alkali metal $\mathrm{K}$ and alkaline earth metal $\mathrm{Ca}$, they increased the gas and reduced the condensable organic compounds. The catalytic effect of $\mathrm{Ca}(\mathrm{OH})_{2}$ was comparatively superior to $\mathrm{K}_{2} \mathrm{CO}_{3}$. However, the role of $\mathrm{K}_{2} \mathrm{CO}_{3}$ might have been underestimated. Because $\mathrm{K}_{2} \mathrm{CO}_{3}$ forms glass by reacting with silicon dioxide at the temperature around $800^{\circ} \mathrm{C}$. Based on the results of the present study, it can be concluded that $\mathrm{K}_{2} \mathrm{CO}_{3}$ and $\mathrm{Ca}(\mathrm{OH})_{2}$ have the catalytic effect to decompose the tar to enhance gaseous production even when it was reacted with silicon dioxide. Also, temperature conditions of secondary pyrolysis and gasification of tar is important to reduce the amount of tar. In the case of using ash as a catalyst, it is necessary to take into account the reactivity between the fluidizing medium and ash.

\section{ACKNOWLEDGEMENT}

Some parts of this study were supported by the special funds for Basic Research (B) (No. 22404022, FY2010-2012) of Grant-in-Aid for Scientific Research of the Japanese Ministry of Education, Culture, Sports, Science and Technology (MEXT), Japan.

\section{REFERENCES}

[1] Lin, S., World gasification process development for syngas production. Journal of the Japan Institute of Energy, 91, pp. 826-834, 2012. 
[2] Zhang, R., Brown, R.C., Suby, A. \& Cummer, K., Catalytic destruction of tar in biomass derived producer gas. Energy Conversion and Management, 45, pp. 995-1014, 2004. doi: http://dx.doi. org/10.1016/j.enconman.2003.08.016

[3] Han, J. \& Kim, H., The reduction and control technology of tar during biomass gasification/ pyrolysis: an overview. Renewable and Sustainable Energy Reviews, 12, pp. 397-416, 2008. doi: http://dx.doi.org/10.1016/j.rser.2006.07.015

[4] Hayashi, J., Iwatsuki, M., Morishita, K., Tsutsumi, A., Li, C. \& Chiba, T., Roles of inherent metallic species in secondary reactions of tar and char during rapid pyrolysis of brown coals in a drop-tube reactor. Fuel, 81, pp. 1977-1987, 2002. doi: http://dx.doi.org/10.1016/S00162361(02)00128-X

[5] Shen, D.K. \& Gu, S., The mechanism for thermal decomposition of cellulose and its main products. Bioresource Technology, 100, pp. 6496-6504, 2009. doi: http://dx.doi.org/10.1016/j. biortech.2009.06.095

[6] Wang, Q., Endo, T., Apar, P., Gui, L., Chen, Q., Mitsumura, N., Qian, Q., Niida, H., Animesh, S. \& Sekiguchi, K., Study on heterogeneous reaction between tar and ash from waste biomass pyrolysis and gasification. WIT Transactions on Ecology and the Environment, Vol. 176, Energy and Sustainability IV, eds. C.A. Brebbia, A.M. Marinov \& C.A. Safta, WIT Press: Southampton, pp. 291-302, 2013.

[7] Gomez-Barea, A. \& Leckner, B., Modeling of biomass gasification in fluidized bed. Progress in Energy and Combustion Science, 36, pp. 444-509, 2010. doi: http://dx.doi.org/10.1016/j. pecs.2009.12.002

[8] Yang, H., Yan, R., Chen, H., Lee, D.H. \& Zheng, C., Characteristics of hemicelluloses, cellulose and lignin pyrolysis. Fuel, 86, pp. 1781-1788, 2007. doi: http://dx.doi.org/10.1016/j. fuel.2006.12.013

[9] Hosoya, T., Kawamoto, H. \& Saka, S., Pyrolysis gasification reactivities of primary tar and char fractions from cellulose and lignin as studied with a closed ampoule reactor. Journal of Analytical and Applied Pyrolysis, 83, pp. 71-77, 2008. doi: http://dx.doi.org/10.1016/j. jaap.2008.06.002

[10] Levin, E.M., Robbins, C.R. \& Mcmurdie, H.F., Phase Diagrams for Ceramists, Volume I: Oxides and Salts, American Ceramic Society: Westerville, OH, United States, 1986.

[11] Bourhis, E.L., Glass, John Wiley \& Sons: New York, United States, 2008.

[12] Lehman, R.L., Gentry, J.S. \& Glumac, N.G., Thermal stability of potassium carbonate near its melting point. Thermochimica Acta, 316, pp. 1-9, 1998. doi: http://dx.doi.org/10.1016/S00406031(98)00289-5

[13] Fryda, L.E., Panopoulos, K.D. \& Kakaras, E., Agglomeration in fluidized bed gasification of biomass. Powder Technology, 181, pp. 307-320, 2008. doi: http://dx.doi.org/10.1016/j.powtec.2007.05.022

[14] Widyawati, M., Church, T.L., Florin, N.H. \& Harris, A.T., Hydrogen synthesis from biomass pyrolysis with in situ carbon dioxide capture using calcium oxide. International Journal of Hydrogen Energy, 36, pp. 4800-4813, 2011. doi: http://dx.doi.org/10.1016/j.ijhydene.2010.11.103

[15] Tingyu, Z., Shouyu, Z., Jiejie, H. \& Yang, W., Effect of calcium oxide on pyrolysis of coal in a fluidized bed. Fuel Processing Technology, 64, pp. 271-284, 2000. doi: http://dx.doi. org/10.1016/S0378-3820(00)00075-8 